\title{
Digestibility of grass silage
}

\author{
A. STEG, S. F. SPOELSTRA, J. M. VAN DER MEER \& V. A. HINDLE
}

Research Institute for Livestock Feeding and Nutrition, P.O.Box 160, NL 8200 AD Lelystad, Netherlands

Received 8 January 1990; accepted 19 February 1990

\begin{abstract}
Grass silage is a very important ruminant winter feed in the Netherlands. The nutritive value of grass silage can, however, vary considerably. Varying influences attributed to grass growth stage at harvesting, botanical composition, harvesting conditions, ensiling processes and post-ensiling events complicate the accurate prediction of the feeding value based on laboratory analyses. Fifty grass silages were tested in digestibility trials with wethers. The feeds tested included mainly wilted silages of varying dry matter content as well as silages treated with cell-wall degrading enzymes. The accuracy of feed evaluation was studied using laboratory analyses, including cell-wall analyses, incubation in vitro with rumen fluid and the enzymatic procedure. A comparison was made between these results and the current and recently suggested procedures for prediction of digestibility of grass silage.
\end{abstract}

Keywords: grass silage, chemical composition, digestibility, enzyme treatment, grass-herb vegetations

\section{Introduction}

Correct feed evaluation is imperative for adequate feeding and supplementation of grass silage to the ruminant. Current evaluation systems are focussed on available (metabolizable or net) energy (van der Honing \& Steg, 1989). In practice the energy value of feeds is calculated from digestible organic components determined with sheep fed at maintenance requirement for energy or predicted directly from chemical characteristics or in-vitro digestion analyses. In the Netherlands the service laboratories analyse approximately 80000 farm silage samples annually for forage evaluation. Routinely, the predictions concerning organic matter digestibility are still calculated using proximate analysis. The regression equations which are applied have been derived from the results of grass silage digestibility trials with sheep performed in the period 1950-1975 (Anonymous, 1977) which contained few samples of wilted silages. Since then the amount of grass silage made in the Netherlands has increased to $4 \mathrm{Mt}$ DM per year, virtually all as wilted silages.

Wilting to a dry matter content above $300 \mathrm{~g} \mathrm{~kg}^{-1}$ prior to ensiling has been shown to enhance successful fermentation. In doing so, a daily decrease in organic 
matter (OM) digestibility of $1 \%$ (with considerable variation) has to be accepted (Spoelstra \& Hindle, 1989). Wilting also reduces the ratio of protein-N to total-N (Thomas \& Thomas, 1985; Tamminga et al., 1990). Therefore, wilting complicates the feed evaluation of the silage.

A further complication to feed evaluation of grass silage is the recently introduced usage of cell-wall degrading enzymes as additive at ensiling. Addition of these enzymes results in lower levels of cell-wall compounds, particularly for low dry-matter silages. However, according to in vitro and in vivo studies, the fraction which is not apparently digested appears to remain unchanged (van Vuuren et al., 1989; Spoelstra et al., 1990).

Most of the grassland in the Netherlands is used intensively and high levels of $\mathrm{N}$ fertilizer are applied. Perennial ryegrass grows quite well under these environmental conditions and has become the predominant grass species in most Dutch pastures. However, in wet, peaty areas other grass species are more competitive. In the increasing area designated to nature conservation farming restrictions result in a variety of grass and herb species in the sward which complicate the estimation of its feeding value because of differences between plant species in the level and composition of cell walls and the different relationships of these with digestibility (Korevaar et al., 1988).

The variation in feeding value of silages is due to variation in feeding value of grass resulting from differences in botanical composition, weather conditions during grass growth, the rate and type of fertilization, the stage of maturity at cutting and the conditions at wilting and harvesting (Thomas \& Thomas, 1985). Silage fermentation adds to the variability in feeding value.

These changes in grassland management and silage making are likely to affect the accuracy of feed evaluation of grass silage as practised by the service laboratories. The present study aims to evaluate current Dutch prediction methods and recently published regression equations using the results obtained from recently performed animal experiments.

\section{Materials and methods}

During the period 1980 to 1989 digestibility trials were performed on 50 grass silages. The results were studied for best-fit regressions of digestibility on laboratory analyses. The data-set was also used to validate current prediction methods.

\section{Silages}

The silages studied were:

(1) large clamp wilted grass silages (50-100 t),

(2) samples from pilot-scale experiments on ensiling under poor weather conditions,

(3) experimental silages used in the study of the effect of cell-wall degrading enzymes (Spoelstra et al., 1990), and

(4) mixed grass-herb silages harvested in nature conservation/reserve areas.

A minority of these silages were made with additives as most of the silages were 
wilted; in addition to the enzyme treatments molasses, acetic acid and formic acid were also occasionally used as additive. Except for the three 'nature reserve' silages Lolium perenne was the dominating grass species. The mixed grass-herb swards were reported to contain low levels of perennial ryegrass and higher levels of herbs and of Yorkshire fog (Holcus mollis), floating foxtail (Alopecuris geniculatus) and several bent species (Agrostis canina).

\section{Animal experiments}

The silages were tested in digestibility experiments with four wether sheep of the Texel breed. The silage comprised the whole diet; the daily silage allowance of each animal was aimed to be equivalent to $1 \mathrm{~kg}$ dry matter (about $40 \mathrm{~g}$ dry matter per $\mathrm{kg}$ metabolic live weight). Preceeding the experiments the silages were weighed in relevant daily portions and stored at $-20^{\circ} \mathrm{C}$ up to 24 hours before feeding. At weighing, three composite samples were taken for laboratory analyses. Each silage was fed for at least three weeks. During the last 10 days of each trial all the faeces were collected as well as incidental feed refusals. After completion of the collection period the faeces were homogenised and two composite samples per animal were taken for laboratory analyses.

\section{Chemical analyses}

Chemical analyses were performed according to IVVO standard analytical procedures based upon prescriptions given by the International Organization for Standardization (ISO) or the Dutch Standardization Institute (NNI) and specified by document number (NEN). Laboratory samples were prepared following ISO 6497. Feed as well as faeces samples were analysed for contents of moisture (DM; ISO 6496), ash (A; ISO 5984), crude protein (CP) as N-Kjeldahl (ISO 5983), crude lipids (CFAT; ISO 6492), crude fibre (CF; NEN 3327) and gross energy (GE; NEN-ISO 1928). Feed samples were additionally analysed for $\mathrm{pH}$, volatile fatty acids and alcohols and $\mathrm{NH}_{3}$ (analyses of VFA, alcohols and $\mathrm{NH}_{3}$ on fresh silage as well as after drying) and lactic acid. Neutral detergent fibre (NDF) was determined according to van Soest (1967). Incidently a determination of acid detergent fibre (ADF; van Soest, 1967) and reducing sugars after inversion (Bosma, pers.comm.) were also performed. All chemical characteristics determined in the oven-dried matter were corrected for evaporated organic matter according to the analyses performed. Crude protein in the silage was expressed $\mathrm{NH}_{3}$-free.

\section{In vitro digestibility}

Organic matter digestibility was determined in vitro by incubation with rumen fluid followed by pepsin- $\mathrm{HCl}\left(\mathrm{d}_{\mathrm{Ol}}\right)$ and by incubation with pepsin followed by heating and treatment with cellulase $\left(\mathrm{d}_{\mathrm{Oc}}\right)$. For both in vitro analyses 10 samples of grass silage of known in vivo digestibility, covering a 60-80\% range in OM digestibility $\left(d_{O M}\right)$ were included in each in vitro run. The in vitro result of the test feeds was 
corrected for the differences between in vivo and in vitro digestibility of these standard samples, thus enabling an approximation of the in vivo digestibility. It should be noted that $\mathrm{d}_{\mathrm{O}}$ was determined at the time of execution of the animal trial; however, $d_{O c}$ of the silages was determined in two runs in 1989.

\section{Statistical analyses}

Single and multiple linear regression analyses were applied for the prediction of apparently digestible substances and for validation of proposed equations using the statistical package Genstat 5 (Lane et al., 1987). The chemical variables tested were expressed where relevant on an ash-free basis to avoid complications arising from accidental differences in ash content due to soil contamination.

The results of the statistical analyses were compared with regression equations derived in similar studies by de Boever et al. (1988) and by Givens et al. (1989). A further comparison was made with results from experiments considering the ensilage of wilted grass on a pilot-scale (2-4 tonnes per silo) at relatively low DM contents $\left(<350 \mathrm{~g} \mathrm{~kg}^{-1}\right)$. These experiments were performed to study ensiling under adverse weather conditions for wilting (Corporaal \& Steg, 1990).

\section{Results}

\section{Chemical composition and digestibility}

The chemical composition of the silages is given in Table 1 . The cutting dates ranged between 10 May and 30 August; the average being in mid June. The wilting period ranged from zero ( $=$ direct cut silage) to 10 days; on average 3.1 days. The three silages made from mixed grass-herb vegetations showed relatively low protein and high cell-wall contents.

In Table 2, information is given concerning digestibility in vivo and in vitro. The variation in digestibility was substantially influenced by exclusion of data from trials with grass silages of abnormal botanical composition: the average organic matter digestibility in vivo increased by more than one $\%$ unit and the standard deviation of the population decreased from 5.6 to $4.0 \%$. Parallel trends were observed for the other coefficients of digestion.

\section{Regression analyses}

The apparent digestibilities as measured in vivo for organic matter, crude protein, crude lipids and gross energy were analysed by single and multiple linear regression. The following parameters were employed as variables:

(1) proximate analyses;

(2) in vitro organic matter digestibility $\left(\mathrm{d}_{\mathrm{Ot}}\right)+$ proximate analyses;

(3) in vitro organic matter digestibility $\left(\mathrm{d}_{\mathrm{OC}}\right)+$ proximate analyses.

As cell-wall content was either characterized by NDF or by CF, no analyses including both parameters were reported. The relationship between both cell-wall 
Table 1. Chemical composition of silages (in $\mathrm{g} \mathrm{kg}^{-1} \mathrm{DM}$ unless otherwise stated; averages of 3 samples).

\begin{tabular}{|c|c|c|c|c|c|}
\hline \multirow[b]{2}{*}{ Dry matter $\left(\mathrm{g} \mathrm{kg}^{-1}\right)^{2}$} & \multirow{2}{*}{$\begin{array}{l}\text { Mean } \\
415\end{array}$} & \multirow{2}{*}{$\begin{array}{l}\text { SD1 } \\
146\end{array}$} & \multicolumn{2}{|c|}{ Range } & \multirow{2}{*}{$\begin{array}{l}\mathrm{n} \\
50\end{array}$} \\
\hline & & & 164 & -764 & \\
\hline Total ash & 132 & 41 & 69 & -322 & 50 \\
\hline Crude protein & 187 & 36 & 82 & -242 & 50 \\
\hline Crude lipids & 41 & 10 & 15 & -64 & 46 \\
\hline Crude fibre & 249 & 38 & 180 & -324 & 50 \\
\hline Neutral detergent fibre & 468 & 69 & 313 & -614 & 48 \\
\hline Acid detergent fibre & 270 & 47 & 190 & -392 & 17 \\
\hline Invert sugar & 38 & 33 & 1 & -108 & 16 \\
\hline Lactic acid & 50 & 44 & 1 & -137 & 38 \\
\hline Acetic acid & 11 & 10 & 1 & -47 & 42 \\
\hline Butyric acid & 4 & 5 & 0 & -19 & 41 \\
\hline Ethanol & 8 & 8 & 0 & -39 & 43 \\
\hline Gross energy (MJ kg-1 $\left.\mathrm{DM}^{2}\right)$ & 18.3 & 0.9 & 14. & $1-20.0$ & 50 \\
\hline Ammonia nitrogen $(\%$ total $\mathrm{N})$ & 8 & 4 & & -19 & 50 \\
\hline
\end{tabular}

1 Standard deviation of the population.

2 Corrected for evaporated VFA, alcohol and $\mathrm{NH}_{3}$.

Table 2. Apparent digestibilities of the silages (averages of 2-4 replicates).

Mean $\quad \mathrm{SD}^{1} \quad$ Range

Digestibility in vivo (\%)

$\begin{array}{lllll}\text { Organic matter } & 73.4 & 5.6 & 55.0-81.9 & 50 \\ \text { Crude protein } & 70.3 & 7.7 & 48.1-80.7 & 50 \\ \text { Crude lipids } & 64.9 & 6.4 & 46.7-77.0 & 46 \\ \text { Crude fibre } & 77.0 & 7.0 & 49.2-86.8 & 50 \\ \text { Gross energy } & 69.9 & 5.6 & 51.6-78.3 & \\ & & & \\ \text { Digestibility in vitro (\%) } & & & & 49 \\ & & & 56.3-82.8 & 48 \\ \text { Rumen fluid organic matter } & 73.1 & 5.2 & 58.7-80.4 & \\ \text { Pepsin-cellulase organic matter } & 73.0 & 4.8 & \end{array}$

1 Standard deviation of the population.

characteristics was: NDF $=1.667 \times \mathrm{CF}+51.7$; RSD (residual standard error) $=$ 30 (in $\mathrm{g} \mathrm{kg}^{-1}$ dry matter); $\mathrm{r}=0.91$. The regression analyses were performed for the complete set of silages $(n=50)$ and with reduced sets omitting the enzymetreated silages together with the mixed grass-herbs silages $(n=42)$. A third series of analyses were made on silages without enzyme treatment made on the IVVO experimental farm $(n=27)$. 
A. STEG, S. F. SPOELSTRA, J. M. VAN DER MEER AND V. A. HINDLE

Table 3. Best-fit predictions of organic matter digestibility $\left(d_{O M}\right)$ in vivo $(\%)$ from chemical composition by multivariate regression (dry matter in $\mathrm{g} \mathrm{kg}^{-1}$; ash in $\mathrm{g} \mathrm{kg}^{-1} \mathrm{DM}$; CP, CF and NDF in $\mathrm{g} \mathrm{kg}^{-1}$ $\mathrm{OM})$.

\begin{tabular}{lllllll}
\hline $\begin{array}{l}\text { Equation } \\
\text { number }\end{array}$ & $\begin{array}{l}\text { Independent } \\
\text { variables }\end{array}$ & Constant & $\begin{array}{l}\text { Regression } \\
\text { coefficient }\end{array}$ & $\begin{array}{l}\text { Variance } \\
\text { accounted } \\
\text { for }(\%)\end{array}$ & RSD & $\mathrm{n}$ \\
& & &
\end{tabular}

Whole sample set

1

Crude fibre

Dry matter

Ash

2

Neutral detergent fibre

Crude protein

Ash

$$
+111.8
$$

$-0.0994$

$-0.01006$

$-0.0434$

$+92.1$

$-0.0459$

$+0.0533$

$-0.0419$

55.8

3.850

67.9

$3.2 \quad 48$

Restricted set 1

3

$+107.8$

53.5

$2.7 \quad 42$

Crude fibre

Ash

Dry matter

4

$+108.3$

$-0.0789$

$-0.048$

$-0.0112$

58.2

$2.6 \quad 42$

Neutral detergent fibre

Ash

$-0.05418$

$-0.03677$

Restricted set 2

5

$+110.7$

60.0

2.7

27

Crude fibre

Ash

$-0.0842$

$-0.0583$

Dry matter

6

$+109.3$

$-0.01124$

Neutral detergent fibre

Ash

$-0.05352$

$-0.0483$

Table 3 shows the best-fit linear regression equations for the prediction of the organic matter digestibility $\left(\mathrm{d}_{\mathrm{OM}}\right)$ from chemical analyses. In each of the analyses mentioned the significance of the contribution from CP, CF (or NDF), ash, DM content, ammonia nitrogen ( $\%$ of total $\mathrm{N}$ ), cutting date, and length of wilting period was tested. Linear regression coefficients for cutting date and wilting period, although negative, were never statistically significantly different from zero. The same applied for the effect of ammonia- $\mathrm{N} \%$ on $\mathrm{d}_{\mathrm{OM}}$. 


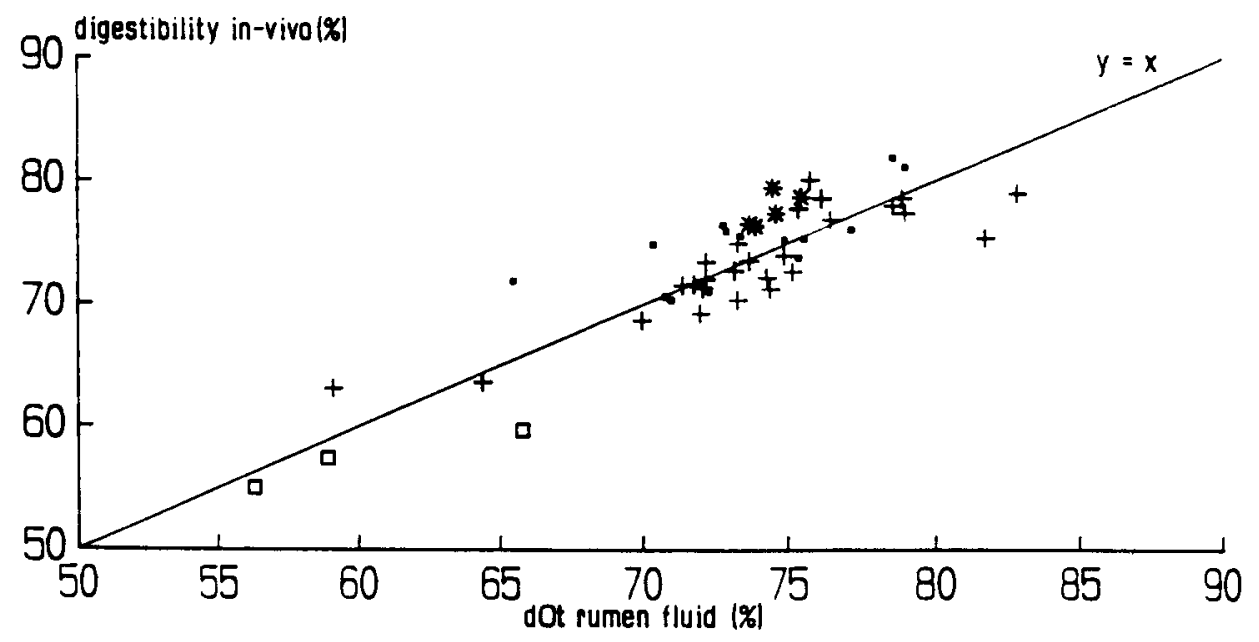

Fig. 1. Relationship between organic matter digestibility in vivo $\left(\mathrm{d}_{O M}\right)$ and organic matter digestibility in vitro (rumen fluid based; $\mathrm{d}_{\mathrm{Ol}}$ ). $\bullet=$ Others, $+=$ IVVO, ${ }^{*}=$ enzyme-treated, $\mathrm{a}=$ mix of grass and herbs.

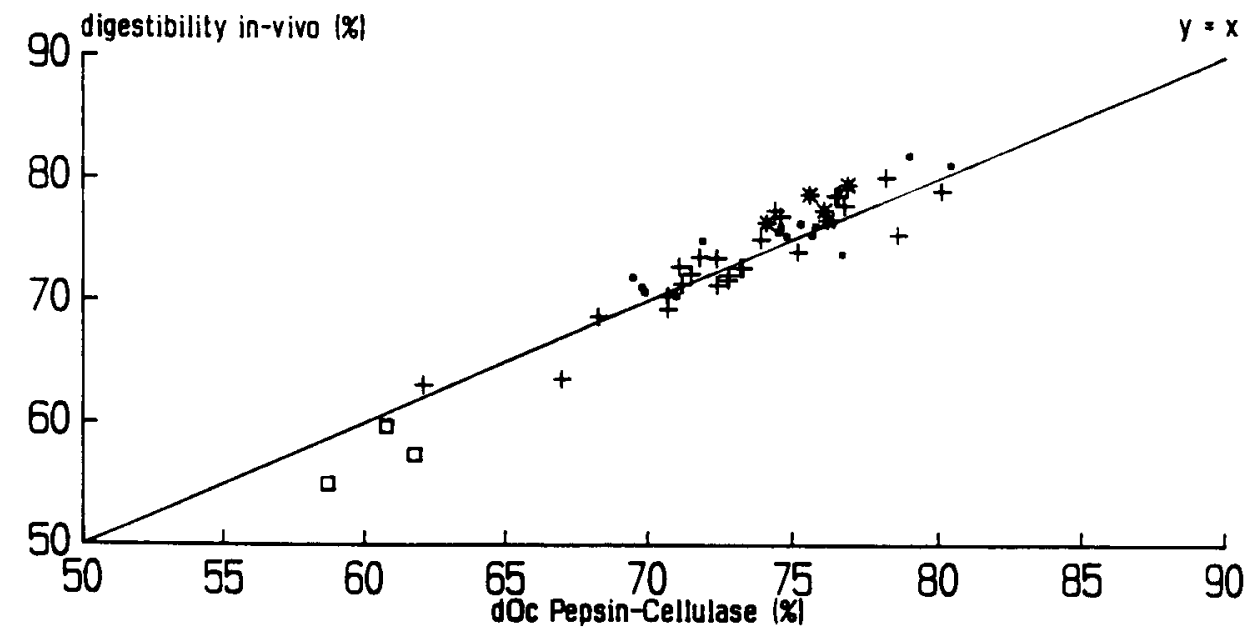

Fig. 2. Relationship between organic matter digestibility in vivo $\left(\mathrm{d}_{\mathrm{OM}}\right)$ and organic matter digestibility in vitro (cellulase based; $d_{O c}$ ). $\bullet=$ Others, $+=$ IVVO, ${ }^{*}=$ enzyme-treated, $\square=$ mix of grass and herbs.

Figures 1 and 2 show the relationships between OM digestibility determined in vivo with the respective in vitro predictions using either rumen fluid or enzymes. Contrary to $d_{O t}$ the regression coefficient for $d_{O c}$ on $d_{O M}$ differed significantly from unity and the constant differed significantly from zero. 
Table 4. Prediction of organic matter digestibility $\left(\mathrm{d}_{\mathrm{OM}} ; \%\right)$ from organic matter digestibility in vitro $\left(\mathrm{d}_{\mathrm{O} 1}\right.$ : rumen fluid based; $\mathrm{d}_{\mathrm{Oc}}$ : cellulase based) and ammonia-N (\% total-N).

\begin{tabular}{|c|c|c|c|c|c|c|}
\hline $\begin{array}{l}\text { Equation } \\
\text { number }\end{array}$ & $\begin{array}{l}\text { Independent } \\
\text { variables }\end{array}$ & Constant & $\begin{array}{l}\text { Regression } \\
\text { coefficient }\end{array}$ & $\begin{array}{l}\text { Variance } \\
\text { accounted } \\
\text { for }(\%)\end{array}$ & RSD & $\mathrm{n}$ \\
\hline 7 & $\mathrm{~d}_{\mathrm{Ot}}$ & +3.64 & +0.9549 & 76.8 & 2.7 & 49 \\
\hline 8 & $\begin{array}{l}d_{O t} \\
\text { Ammonia-N (\%) }\end{array}$ & -1.61 & $\begin{array}{l}+0.9991 \\
+0.249\end{array}$ & 78.6 & 2.6 & 49 \\
\hline 9 & $d_{O c}$ & -10.5 & +1.1491 & 91.1 & 1.7 & 48 \\
\hline 10 & $\begin{array}{l}\mathrm{d}_{\mathrm{Oc}} \\
\text { Ammonia-N (\%) }\end{array}$ & -13.6 & $\begin{array}{l}+1.1723 \\
+0.168\end{array}$ & 92.0 & 1.6 & 48 \\
\hline
\end{tabular}

Table 5. Prediction of digestible crude protein and digestible crude lipids from crude protein and crude lipids, respectively (data in $\mathrm{g} \mathrm{kg-1}^{-1}$ organic matter).

\begin{tabular}{|c|c|c|c|c|c|c|}
\hline $\begin{array}{l}\text { Equation } \\
\text { number }\end{array}$ & $\begin{array}{l}\text { Independent } \\
\text { variables }\end{array}$ & Constant & $\begin{array}{l}\text { Regression } \\
\text { coefficient }\end{array}$ & $\begin{array}{l}\text { Variance } \\
\text { accounted } \\
\text { for }(\%)\end{array}$ & RSD & $\mathrm{n}$ \\
\hline
\end{tabular}

Prediction of digestible crude protein

11

$$
\text { Crude protein }
$$$$
-47.8
$$$$
+0.9368
$$

95.4

9

50

Prediction of digestible crude lipids

12

Crude lipids
$-7.4$ $+0.8154$
94.0

2

47

Best-fit (multiple) regression equations using $\mathrm{d}_{O t}$ and $\mathrm{d}_{O c}$ on the whole set $(\mathrm{n}=$ 50) are given in Table 4. Inclusion of CP, NDF, CF, DM, ash, cutting date or days wilting did not significantly improve the amount of variance accounted for.

For $n=42$ the RSD of the regression on $d_{O t}$ was reduced to $2.4 \%$. However, the percentage variance accounted for also decreased due to a considerable reduction in variance of the set. No significant additional influence of ammonia- $\mathrm{N}$ was calculated. For $\mathrm{n}=27$ a further reduction in RSD was observed for the regression on $\mathrm{d}_{\mathrm{Ot}}$ with $5 \%$ increase in the percentage accountable variance.

Table 5 gives information on apparent digestibility prediction for protein and lipids. The calculation of DCP from CP and DFAT from CFAT was made as the 
Table 6. Prediction of energy digestibility $\left(\mathrm{d}_{\mathrm{GE}} ; \%\right)$ from organic matter digestibility in vitro $\left(\mathrm{d}_{\mathrm{O} 1}\right.$ : rumen fluid based; $d_{O c}$ : cellulase based) and crude lipids ( $\mathrm{g} \mathrm{kg}^{-1}$ organic matter).

\begin{tabular}{|c|c|c|c|c|c|c|}
\hline $\begin{array}{l}\text { Equation } \\
\text { number }\end{array}$ & $\begin{array}{l}\text { Independent } \\
\text { variables }\end{array}$ & Constant & $\begin{array}{l}\text { Regression } \\
\text { coefficient }\end{array}$ & $\begin{array}{l}\text { Variance } \\
\text { accounted } \\
\text { for }(\%)\end{array}$ & RSD & $\mathrm{n}$ \\
\hline 13 & $\mathrm{~d}_{\mathrm{Ot}}$ & +3.2 & +0.9128 & 71.1 & 3.0 & 49 \\
\hline 14 & $\begin{array}{l}\mathrm{d}_{\mathrm{O} t} \\
\text { Crude lipids }\end{array}$ & +9.8 & $\begin{array}{r}+0.6696 \\
+0.2359\end{array}$ & 86.6 & 2.1 & 47 \\
\hline 15 & $\mathrm{~d}_{\mathrm{Oc}}$ & -12.5 & +1.1282 & 88.5 & 1.9 & 48 \\
\hline 16 & $\begin{array}{l}\mathrm{d}_{\mathrm{O}_{c}} \\
\text { Crude lipids }\end{array}$ & -4.2 & $\begin{array}{l}+0.9345 \\
+0.1246\end{array}$ & 91.8 & 1.7 & 46 \\
\hline
\end{tabular}

apparent digestibility of protein and lipids depends largely on the levels of $\mathrm{CP}$ and CFAT in the feeds.

No improvements in the percentage of variance could be accounted to additions to those parameters mentioned in Table 5 . Neither did reduction of the sample set.

Energy digestibility was found to be closely correlated with organic matter digestibility. In the equation $\mathrm{d}_{\mathrm{GE}}=0.9812 \mathrm{~d}_{\mathrm{OM}}-2.1(\mathrm{n}=50), 97.7 \%$ of the variance could be accounted for, the RSD being $0.86 \%$. No improvement to this was observed for the reduced sample sets. Single and multiple regression of $d_{G E}$ on laboratory analyses were tested. The best-fit regressions for the whole set are displayed in Table 6.

For the sample selections a more accurate prediction of $\mathrm{d}_{\mathrm{GE}}$ could be calculated from either $d_{O}$ or $d_{O C}$ as single parameters but no improvement was obtained over regressions including the level of lipids. Correction for differences in either $\mathrm{CP}, \mathrm{CF}$ or NDF did not improve the prediction power.

\section{Validation of proposed DOMD prediction equations}

The best-fit regression equations for $\mathrm{d}_{O M}$ may be converted to prediction equations for contents of digestible organic matter in dry matter (DOMD) by additional correction for ash content. The data-set was also used to validate some recently published prediction equations and the prediction equations currently used by the service laboratories in the Netherlands (Anonymous, 1977). Results are given in Table 7. Figures 3 and 4 show the relationships between DOMD and the latter equations.

The laboratory data as determined at the IVVO were used for the validation (for example assuming IVDOMD $=\mathrm{d}_{\mathrm{Ot}} \times \mathrm{OM} / 100$ ). It should be considered that the equation derived by Corporaal \& Steg (1990) was based upon $\mathrm{d}_{\mathrm{Ot}}$ data with corrections for in vivo/in vitro differences as described earlier. 
Table 7. Validation of some predictions for contents of digestible organic matter in dry matter (DOMD, $\mathrm{g} \mathrm{kg}^{-1}$ ) on the whole data set (IVDOMD = rumen fluid based/CDOMD = pepsin-cellulase based in vitro digestible organic matter in dry matter). Data in DM ( $\left.\mathrm{g} \mathrm{kg}^{-1}\right)$.

$\begin{array}{llllll}\text { Constant } & \begin{array}{l}\text { Regression } \\ \text { coefficient }\end{array} & \begin{array}{l}\text { Independent } \\ \text { variables }\end{array} & \begin{array}{l}\text { Variance } \\ \text { accounted } \\ \text { for }(\%)\end{array} & \begin{array}{l}\text { Standard } \\ \text { error of } \\ \text { performance }\end{array} & \text { Bias } \\ & & & & & \end{array}$

Direct calculations

$\mathrm{d}_{\mathrm{O}} \times \mathrm{OM}\left(\mathrm{g} \mathrm{kg}^{-1}\right) / 100$

$\begin{array}{lll}77 & 24 & -3 \\ 90 & 17 & -3\end{array}$

$\mathrm{d}_{\mathrm{Oc}} \times \mathrm{OM}\left(\mathrm{g} \mathrm{kg}^{-1)}\right) / 100$

Regressions

De Boever et al. (1988) +242

$\begin{array}{ll}+0.686 & \text { IVDOMD } \\ -0.207 & \text { Ash }\end{array}$

79

30

De Boever et al. (1988) +377

$+0.499$

73

30

$-1$

$-0.432$

CDOMD

Ash

Givens et al. (1989)

$+194$

$+0.77$

$+1.24$

$-0.85$

57

39

$-17$
IVDOMD
Ether extract
Ash

Corporaal \& Steg (1990) + 1054

$-0.77$

$-1.23$

Crude fibre

66

34

$-4$

$-0.03$

$-0.3$

Ash

Dry matter

cdi2 $^{2}$

Anonymous $^{3}$ (1977)

$+1094$

$-1.1$

$-1.094$

65

35

$+5$

$-2.7$

Crude fibre

Ash

Ammonia-N (\%)

1 Windham et al. (1989).

2 Cutting date index: days in the year (0-365).

3 With additional corrections for cutting date; wilting period; DM content if $\mathrm{DM}<350 \mathrm{~g} \mathrm{~kg}^{-1}$.

\section{Discussion}

\section{Chemical composition and digestibility}

The range in dry matter content of the silages studied was comparable to those of de Boever et al. (1988) and Givens et al. (1989). On average, however, dry matter in our silages ( $415 \mathrm{~g} \mathrm{~kg}^{-1}$ ) was considerably higher than given by Givens et al. (1989) (284 $\left.\mathrm{g} \mathrm{kg}^{-1}\right)$ and de Boever et al. (1988) (314 $\left.\mathrm{g} \mathrm{kg}^{-1}\right)$. This reflects the practice of intensive wilting in the Netherlands. 


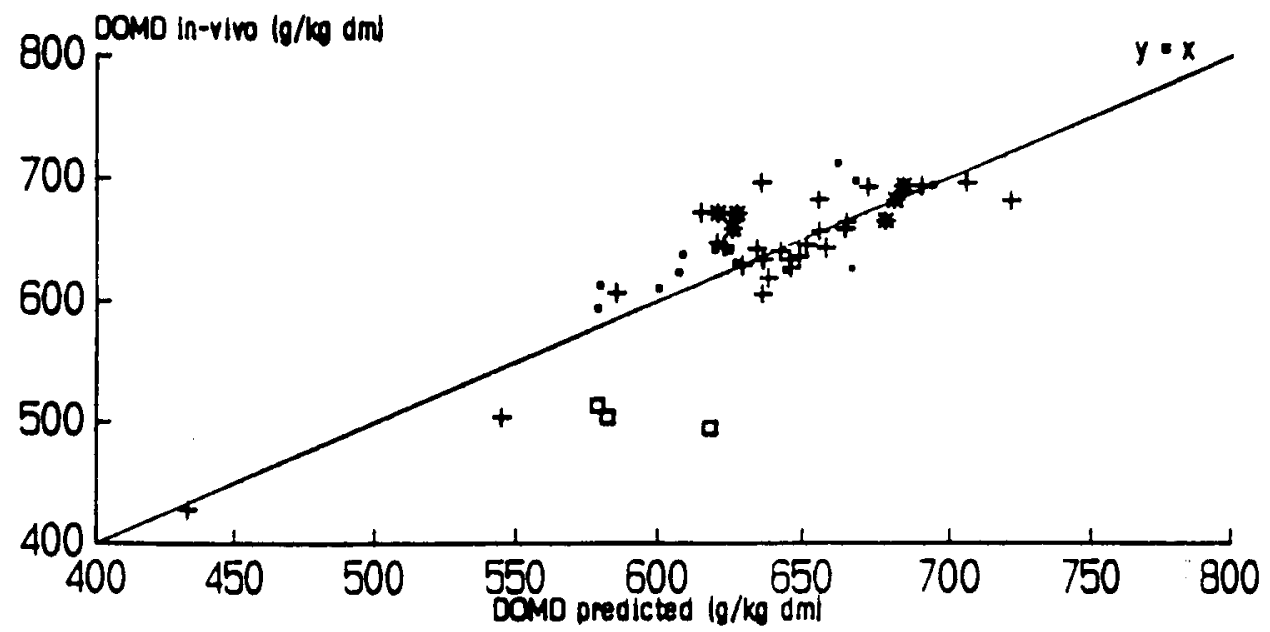

Fig. 3. Relationship between contents of digestible organic matter in dry matter in vivo (DOMD) and DOMD (predicted) according to Corporaal \& Steg (1990). $\bullet=$ Others, $+=$ IVVO, $*=$ enzymetreated, $\square=$ mix of grass and herbs.

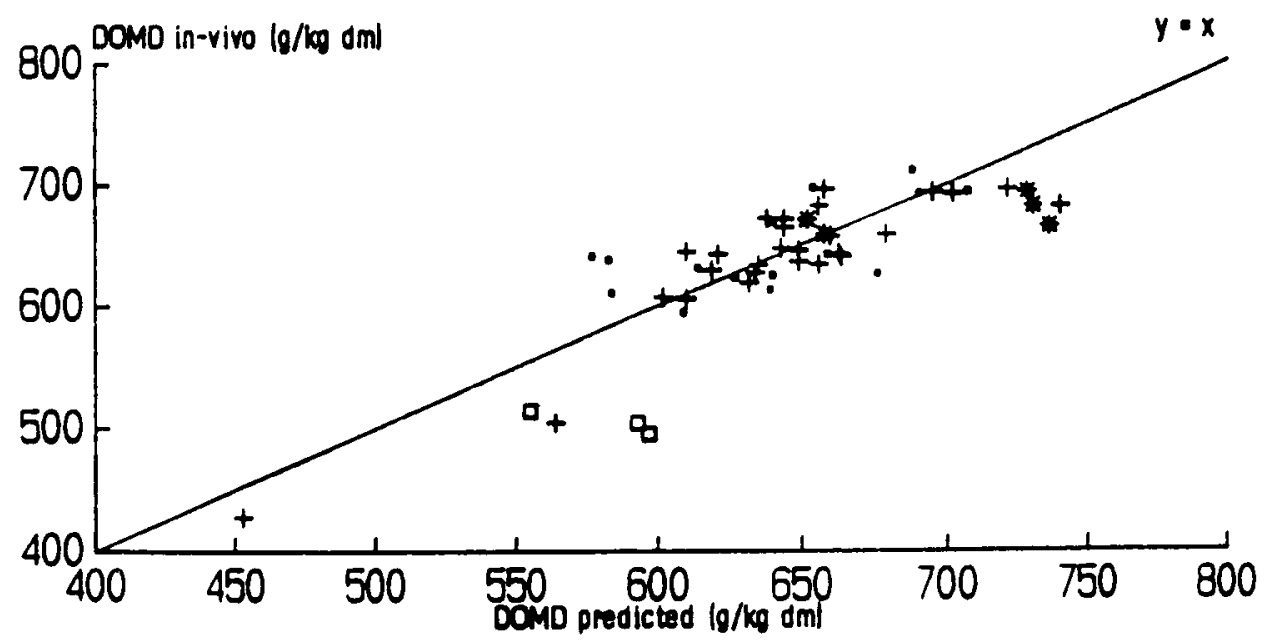

Fig. 4. Relationship between contents of digestible organic matter in dry matter in vivo (DOMD) and DOMD (predicted) according to Anonymous (1977). $\bullet=$ Others, $+=$ IVVO, * = enzyme-treated, $\square=$ mix of grass and herbs.

The average composition of the dry matter was very similar to that determined by Corporaal \& Steg (1990) studying over 500 pilot-scale silages. In our study, the average protein content was $30-40 \mathrm{~g} \mathrm{~kg}^{-1}$ higher and the average fibre content somewhat lower than those found by de Boever et al. (1988) and Givens et al. (1989) 
suggesting that the grass was cut at an earlier growth stage. The average ash content of our silages was approx. $50 \mathrm{~g}$ per $\mathrm{kg}$ dry matter higher than Givens et al. (1989); the upper limit of the range in ash content studied by Givens et al. (1989) was just above the average of our data. The difference observed may be a reflection of differences in fertilization, cutting regime, wilting (wilting in a windrow versus tedding and raking) and harvesting. As might be expected, along with a higher average dry matter content lower levels of fermentation products together with a lower ammonia- $\mathrm{N}$ fraction were observed in comparison to the data of Givens et al. (1989).

The average gross energy content of the silages was almost identical to that found by Givens et al. (1989), when expressed on an organic matter basis (21 $\left.\mathrm{MJ} \mathrm{kg}^{-1}\right)$. When correcting for the ash content the variation in GE was significantly reduced to a standard deviation of $0.7 \mathrm{MJ}$ per $\mathrm{kg}$ organic matter. According to Andrieu \& Demarquilly (1987) the average GE in organic matter should be corrected for differences in crude protein content. However, in our analysis GE (MJ kg-1 OM) was only significantly affected by correcting for lipid content (CFAT; $\mathrm{g} \mathrm{kg}^{-1} \mathrm{OM}$ ): GE $=19.2+4.2$ CFAT $($ RSD $=0.5 \mathrm{MJ})$; with $46 \%$ of the variance accounted for. The equation proposed by Andrieu \& Demarquilly (1987) underestimated GE in our silages by on average $1 \%$. The similarity in GE level with the UK data is worth mentioning because Givens et al. (1989) determined GE as such and our data referred to GE determined in oven-dried samples and corrected for VFA and alcohols evaporated during drying. In doing so differences in gross energy content of the fermentation products concerned were not taken into account. Correcting for these differences (Edwards, 1986) would have changed only marginally the GE content of the silages studied (not more than $100 \mathrm{~kJ}$ per kg dry matter) and exerted negligable effect on the average. So, the GE determination on dried instead of fresh silage samples does not introduce important differences.

Average and range of organic matter and energy digestibilities of the silages studied were very similar to the data of Givens et al. (1989) despite differences in fibre content. This may be a reflection of the slightly increased level of spontaneous cell-wall degradation in low dry matter silages which was not evident in apparent digestibility (Corporaal \& Steg, 1990). In addition, five of the silages were treated with cell-wall degrading enzymes, decreasing the level of CF, NDF and ADF up to $25 \%$ compared to control silages. However, enzyme treatment of these silages did not significantly affect organic matter digestibility in vivo or in vitro (Spoelstra et al., 1990).

\section{Prediction of digestibility or digestible components}

As is also evident from the data given in Table 3, using NDF instead of CF improved the accuracy of prediction of $\mathrm{d}_{\mathrm{OM}}$. In all the equations mentioned the ash content exerted a statistically significant negative effect on the relationship between the organic matter digestibility and the cell-wall parameter considered. A similar observation was made by Corporaal \& Steg (1990) and is also evident from the information obtained from de Boever et al. (1988). Therefore, the general observation of organic 
matter digestibility being directly related with CF, NDF or ADF is complicated by a considerable influence attributable to ash. The regression coefficients for CF were similar in analyses 1, 3 and 5 (and for Corporaal \& Steg, 1990) and higher than -1.0 . For routine purposes at present a coefficient of -1.1 is applied (Anonymous, 1977). Equations 1 and 2 with an RSD above $3 \%$ units are obviously not accurate enough. Comparison with equations 3-6 displays the deviating effects of the silages made from mixed grass-herb vegetations and with enzyme-treatment. In particular overestimations of digestibility (up to $10 \%$ ) were made for the mixed grass-herb silages.

Figures 1 and 2 and Table 4 show the superiority of in vitro digestibility over chemical characteristics for the prediction of in vivo digestibility, particularly for the whole set of silages. Predictions using enzyme-based analysis were surprisingly more accurate than the rumen fluid method. This observation contrasts with the findings by de Boever et al. (1988) and Givens et al. (1989). Both authors found superiority of $\mathrm{d}_{\mathrm{Ot}}$ over $\mathrm{d}_{\mathrm{Oc}}$ at levels of accuracy comparable with our data. However, it should be realized that our data on $\mathrm{d}_{\mathrm{Ot}}$ were determined at the execution of the animal trials; during the last 10 years. The enzyme-based analyses were performed in two runs of analyses in 1989; thus to some extent complicating a direct comparison of the two sets of data. When observing the very accurate $d_{O c}$ predictions the samples were also tested for rumen fluid digestibility in a single sequence in 1989 . Again the average organic matter digestibility found in vitro approached the level determined in vivo. The accuracy in terms of residual standard deviation was $0.3 \%$ units better than that mentioned for $\mathrm{d}_{\mathrm{Ot}}$ in Table 4 , so the superiority of $\mathrm{d}_{\mathrm{Oc}}$ over $\mathrm{d}_{\mathrm{Ot}}$ was slightly reduced. The calibration procedure applied as described for both methods aimed at a direct prediction of $\mathrm{d}_{\mathrm{OM}}$. However, the regression coefficient of the linear relationship between $d_{O c}$ and $d_{O M}$ differed from unity and resulted in a significantly negative intercept, suggesting that in contrast to $\mathrm{d}_{\mathrm{Ot}}$ the calibration set used for $\mathrm{d}_{O c}$ did not completely cover the range of samples concerned.

Besides $\mathrm{d}_{\mathrm{Ot}}$ or $\mathrm{d}_{\mathrm{Oc}}$ only addition of ammonia- $\mathrm{N}$ fraction marginally improved the prediction of $\mathrm{d}_{\mathrm{OM}}$. The positive effect accredited to the ammonia- $\mathrm{N}$ fraction might be explained by a significant correlation between the ammonia- $\mathrm{N}$ fraction and the level of fermentation. In silages with high levels of volatile fermentation products the in vitro methods slightly underestimate the in vivo digestibility, because implicitly only a correction is made for the levels of volatile substances of the samples in the calibration set and these samples were all high DM silages with restricted fermentation.

Upon omission of those samples not originating from the IVVO experimental farm and all enzyme-treated silages, the RSD of the regression of $d_{O M}$ on $d_{O t}$ fell from 2.7 to $2.2 \%$. This indicates that an adaptation of the calibration set to include expected variation in botanical composition and possibly enzyme-treated silages is advisable for a more accurate prediction of the whole range of silages.

The data in Table 5 show that the variation in the apparently digestible protein can be accurately predicted (RSD $=9 \mathrm{~g} \mathrm{~kg}^{-1} \mathrm{OM}$ ) using the crude protein content irrespective of other silage characteristics. The relationship between lipid content and apparently digestible lipids was - as expected - very close (RSD $=2 \mathrm{~g} \mathrm{~kg}^{-1}$ 
OM). As a result a satisfactorily accurate prediction of the apparently digestible carbohydrate fraction can be obtained using data from proximate analysis and in vitro OM digestibility.

The direct prediction of energy digestibility $\left(d_{\mathrm{GE}}\right)$ from $d_{\mathrm{OM}}$ (Table 6) was accurate $(\mathrm{RSD}=0.86 \%$ ). Both correlation coefficient and RSD were similar to a formula based on 19 silage data published by Andrieu \& Demarquilly (1987). Upon comparison, both equations gave very similar predictions of $\mathrm{d}_{\mathrm{GE}}$ in the normal range of $\mathrm{d}_{\mathrm{OM}}$. It is interesting to notice that the prediction of the energy digestibility from $\mathrm{d}_{\mathrm{Ot}}$ or $\mathrm{d}_{\mathrm{Oc}}$ (Table 6) was improved when corrections were made for differences in lipid content ( $\mathrm{RSD}=2.1$ and $1.7 \%$, respectively). This may be explained by an apparent digestibility exceeding $80 \%$ for additional lipids (Table 5) and by the energy density of lipids. Likewise, Givens et al. (1989) reported a negative effect of ether extract on the proportional faecal energy loss from silage.

\section{Validation of DOMD predictions}

The accuracy of DOMD predictions from $\mathrm{d}_{\mathrm{Ot}}$ and $\mathrm{d}_{\mathrm{Oc}}$ are a direct consequence of the relationships between $d_{O M}$ and the in vitro techniques discussed. A correction for ammonia- $\mathrm{N}$ fraction might slightly improve the accuracy of the predictions given in Table 7. According to de Boever et al. (1988), the prediction of DOMD using IVOMD and ash showed a considerable bias. This may be due to the assumption that $\mathrm{d}_{\mathrm{Ot}}$ as determined in our trials multiplied by $\mathrm{OM} / 100$ was numerically equal to IVOMD. In particular the calibration and correction procedure applied in this study differed from their methodology. Correcting for the difference in bias reduced the standard error of performance (SEP) to $27 \mathrm{~g} \mathrm{~kg}^{-1} \mathrm{DM}$. The low regression coefficient $(0.7)$ for IVOMD caused a considerable overestimation of DOMD for poorly digestible silages. The same applied to the DOMD predictions from CDOMD and ash according to de Boever et al. (1988).

The prediction equation derived by Givens et al. (1989) did not fit well with our data. Correction for the average difference between $\mathrm{d}_{\mathrm{O}} \times \mathrm{OM} / 100$ and IVDOMD increased the bias to $30 \mathrm{~g} \mathrm{~kg}^{-1} \mathrm{DM}$. The large negative correction necessary for ash content largely explains this bias. However, since the UK equation was derived from silages with a maximum ash content of $138 \mathrm{~g} \mathrm{~kg}^{-1} \mathrm{DM}$, this equation may not be valid for our silages with higher ash content.

The equation derived by Corporaal \& Steg (1990) based on proximate analysis showed on average a good fit with the data-set. As expected, the accuracy of prediction was inferior to that obtained with inclusion of in vitro data. However, when considering the amount of variance which could be accounted for and the SEP the equation was comparable to those displayed in Table 3. The equation currently used by the Dutch service laboratories slightly overestimated the average DOMD content of the silages. Both prediction equations based on proximate analysis produced a considerable overestimation with silages from mixed grass-herb vegetations due to reasons discussed previously. The overestimation was less pronounced for the enzyme-treated silages. 


\section{Conclusions}

Gross energy content of the grass silages studied was rather constant at $21 \mathrm{MJ}$ per $\mathrm{kg}$ organic matter and was not significantly affected by crude protein content.

The prediction of in vivo organic matter digestibility of grass silage using proximate analysis, as is currently practised by the Dutch service laboratories and as applied in a recently developed alternative equation, showed on average a good fit to data obtained from recent in vivo experiments. However, accuracy of prediction was unsatisfactory, in particular for mixed grass-herb vegetations and for enzymetreated silages.

In vitro digestibility determinations using industrial enzymes or rumen fluid were consistently superior to chemical characteristics in predicting in vivo digestibility. Predictions using the enzyme-based technique were surprisingly more accurate than the rumen fluid method.

Prediction equations obtained in similar studies in UK and Belgium showed considerable bias, when validated with our data.

\section{References}

Andrieu, J. \& C. Demarquilly, 1987. Valeur nutritive des fourrages: tables et prévision. Bulletin Technique CRZV Theix-INRA 70: 61-73.

Anonymous, 1977. Manual for the calculation of the nutritive value of roughages. (In Dutch.) Centraal Veevoederbureau in Nederland, Lelystad.

Beever, D. E., 1986. Feed evaluation: current approach and new opportunities. In: B. A. Stark, D. I. Givens \& J. M. Wilkinson (Eds), Proceedings ADAS nutrition chemistry feed evaluation unit conference, p. 1-21. Chalcombe, Marlow.

Berg, K. \& F. Weissbach, 1976. Untersuchungen zur vollständigen Erfassung des Trockensubstanzgehaltes von Silagen. Archiv für Tierernährung 26: 661-672.

Boever, J. L. de, B. G. Cottyn, J. L. Andries, F. X. Buysse \& J. M. Vanacker, 1988. The use of a cellulase technique to predict digestibility, metabolisable and net energy of forages. Animal Feed Science and Technology 19: 247-260.

Corporaal, J. \& A. Steg, 1990. Sampling, quality and feeding value of grass silage. (In Dutch.) Report Nr. 123, Research Station for Cattle, Sheep and Horse Husbandry, Lelystad.

Edwards, R. A., 1986. The energy value of grass silage. In: B. A. Stark, D. I. Givens \& J. M. Wilkinson (Eds), Proceedings ADAS nutrition chemistry feed evaluation unit conference, p. 35-58. Chalcombe Marlow.

Es, A. J. H. van \& J. M. van der Meer (Eds), 1980. Methods of analysis for predicting the energy and protein value of feeds for farm animals. Proceedings Workshop on methodology of analysis of feeding stuffs for ruminants, Lelystad.

Givens, D. I., J. M. Everington \& A. H. Adamson, 1989. The digestible and metablisable energy content of grass silage and their prediction from laboratory measurements. Animal Feed Science and Technology 24: 27-43.

Greenhalgh, J. F. D. \& F. W. Wainman, 1980. The utilisation of energy in conserved forages. In: C. Thomas (Ed.), Proceedings Symposium 'Forage conservation in the 80's', p. 122-130. British Grassland Society, Hurley.

Honing, Y. van der, A. J. H. van Es, H. J. Nijkamp \& R. Terluin, 1973. Net-energy content of Dutch and Norwegian hay and silage in cattle rations. Zeitschrift für Tierphysiologie, Tierernährung und Futtermittelkunde 31: 149-158.

Honing, Y. van der \& A. Steg, 1989. Comparison of energy evaluation systems of feeds for ruminants. In: W. Haresign \& D. J. A. Cole (Eds), Recent Advances in Animal Nutrition 1989. Butterworth, London (in press). 
Korevaar, H., D. J. den Boer \& Th. V. Vellinga, 1988. Intensive and extensive grassland systems: Implications and restrictions. Proceedings 12th General Meeting European Grassland Federation, Dublin, Ireland, p. 98-115.

Lane, P., N. Galwey \& N. Alvey, 1987. Genstat 5: an introduction. Oxford University Press, Oxford.

Soest, P. J. van, 1967. Development of a comprehensive system of feed analyses and its application to forages. Journal of Animal Science 26: 119-128.

Spoelstra, S. F. \& V. A. Hindle, 1989. Influence of wilting on chemical and microbial parameters of grass relevant to ensiling. Netherlands Journal of Agricultural Science 37: 355-364.

Spoelstra, S. F., A. Steg \& J. W. M. Beuvink, 1990. Application of cell wall degrading enzymes to grass silage. In: J. J. Dekkers, H. C. van der Plas \& D. H. Vuijk (Eds), Agricultural biotechnology in focus in the Netherlands. Pudoc, Wageningen (in press).

Tamminga, S., R. Ketelaar \& A. M. van Vuuren, 1990. Degradation of $\mathrm{N}$ in conserved forages in the rumen of dairy cowes. Grass and Forage Science (in press).

Thomas, C. \& P. C. Thomas, 1985. Factors affecting the nutritive value of grass silage. In: W. Haresign \& D. J. A. Cole (Eds), Recent Advances in Animal Nutrition 1985, p. 223-256. Butterworths, London.

Terry, R. A. \& D. E. Osbourn, 1980. Determination and prediction of the digestible energy in silages. In: C. Thomas (Ed.), Proceedings Symposium 'Forage conservation in the 80's', p. 315-318. British Grassland Society, Hurley.

Vuuren, A. M. van, K. Bergsma, F. Krol-Kramer \& J. A. C. van Beers, 1989. Effects of addition of cellwall degrading enzymes on the chemical composition and the in-sacco degradation of grass silage. Grass and Forage Science 44: 223-230.

Windham, W. R., D. R. Mertens \& F. E. Barton II, 1989. Protocol for NIRS Calibration: Sample Selection and Equation Development and Validation. In: G. C. Marten, J. S. Shenk \& F. E. Barton II (Eds), Near Infrared Reflectance Spectroscopy (NIRS): Analysis of forage quality, p. 96-103. USDA Handbook No. 643. Springfield (USA). 